\title{
PERLINDUNGAN HUKUM BAGI PEMEGANG HAK ATAS TANAH DALAM PENETAPAN GANTI RUGI TERKAIT DENGAN PENGADAAN TANAH UNTUK KEPENTINGAN UMUM
}

\author{
Rizky Amalia \\ WINS \& Partners Law Firm, rizkyamalia07@gmail.com
}

\begin{abstract}
Land acquisition is done by way of release or transfer of land rights of the holders of rights over land to government agencies that require ground. As a form of respect for the rights of holders of land rights, which require land-party in this case is the government agency, provide appropriate compensation on the basis of agreement between both parties through consultation. Form of legal protection given to holders of land rights is the determination of compensation based on the deliberations, the proper compensation that can provide a better survival than the level of socio-economic life before the affected land acquisition, and submission of objections to the amount of indemnification. Custody compensation cannot be the basis for taking land holders of land rights by Government agencies that require ground.
\end{abstract}

Key Words : land acquisition, legal protection, custody compensation.

\begin{abstract}
Abstrak
Pengadaan tanah merupakan suatu lembaga yang digunakan untuk memperoleh tanah bagi pelaksanaan pembangunan untuk kepentingan umum. Perolehan tanah dilakukan dengan cara pelepasan atau penyerahan hak atas tanah dari pemegang hak atas tanah kepada instansi Pemerintah yang memerlukan tanah. Sebagai wujud penghormatan hakhak bagi pemegang hak atas tanah, pihak yang memerlukan tanah dalam hal ini instansi Pemerintah memberikan ganti rugi yang layak atas dasar kesepakatan kedua belah pihak melalui musyawarah. Bentuk perlindungan hukum yang diberikan bagi pemegang hak atas tanah yaitu penetapan ganti rugi didasarkan atas musyawarah, ganti rugi yang layak yang dapat memberikan kelangsungan hidup yang lebih baik dari tingkat kehidupan sosial ekonomi sebelum terkena pengadaaan tanah, serta pengajuan keberatan terhadap besarnya ganti rugi. Penitipan ganti rugi tidak bisa dijadikan dasar untuk mengambil tanah pemegang hak atas tanah oleh instansi Pemerintah yang memerlukan tanah.
\end{abstract}

Kata Kunci : pengadaan tanah, perlindungan hukum, penitipan ganti rugi. 


\section{Pendahuluan}

Indonesia sebagai Negara berkembang membutuhkan pembangunan-pembangunan infrastuktur agar dapat meningkatkan kesejahteraan rakyat Indonesia melalui pembangunan tersebut. Setiap kegiatan pembangunan yang dilaksanakan oleh Pemerintah tentunya tidak dapat terlepas dari kebutuhan akan tanah sebagai wadah kegiatannya. Hal ini dikarenakan pada umumnya kegiatan pembangunan dilakukan di atas tanah. Adanya kebutuhan akan tanah tersebut, membawa konsekuensi terhadap penggunaan tanah oleh pemegang hak atas tanah terkait dengan pengadaan tanah bagi pelaksanaan pembangunan untuk kepentingan umum. Secara konstitusional, Pasal 33 ayat (3) Undang-undang Dasar (UUD) 1945, menyatakan bahwa : "Bumi, air, dan kekayaan alam yang terkandung di dalamnya dikuasai oleh Negara dan dipergunakan untuk sebesar-besar kemakmuran rakyat". Hal ini mendasari hak menguasai dari Negara yang terkandung dalam Undang-undang No.5 Tahun 1960 tentang Peraturan Dasar Pokok-pokok Agraria, yang dikenal dengan sebutan Undang-undang Pokok Agraria (UUPA). Ditegaskan dalam Pasal 2 ayat (2) UUPA, yaitu : "Atas dasar ketentuan dalam Pasal 33 ayat (3) Undang-undang Dasar dan halhal lain sebagai yang dimaksud dalam Pasal 1, bumi, air, dan ruang angkasa, termasuk kekayaan alam yang terkandung di dalamnya itu pada tingkatan tertinggi dikuasai oleh Negara, sebagai organisasi kekuasaan seluruh rakyat". Selain itu, UUPA juga menganut asas hak atas tanah mempunyai fungsi sosial, sebagaimana ditegaskan dalam Pasal 6 UUPA, yaitu : "Semua hak atas tanah mempunyai fungsi sosial”. Asas tersebut mengandung pengertian bahwa pemegang hak atas tanah harus merelakan hak atas tanahnya untuk dilepaskan atau diserahkan apabila Pemerintah membutuhkan tanah tersebut bagi pelaksanaan pembangunan untuk kepentingan umum.

Tanah-tanah yang tersedia untuk memenuhi kebutuhan pembangunan sangat terbatas yang secara langsung dikuasai oleh Negara, dan tanah-tanah yang ada itu hampir semuanya merupakan tanah hak. Meningkatnya kegiatan pembangunan membawa konsekuensi makin banyak dibutuhkan tanah dan nantinya dapat menimbulkan permasalahan-permasalahan di bidang pertanahan. Tidak hanya itu, berjalanya proses pembangunan yang cukup pesat di Negara kita bukan saja memaksa harga tanah pada berbagai tempat untuk naik melambung akan tetapi juga telah menciptakan suasana dimana tanah sudah menjadi "komoditi ekonomi" yang mempunyainilai sangat tinggi sehinggabesar kemungkinan pembangunan selanjutnya akan mengalami kesulitan dalam mengejar laju pertumbuhan harga tanah dimaksud. ${ }^{1}$ Harga tanah akan terus melambung tinggi, sehingga tanah tidak lagi menjadi nilai sosial bagi pemiliknya, namun sudah menjadi nilai ekonomis. Pada akhirnya arti penting tanah bagi pemegang hak atas tanah inilah yang berpengaruh besar terhadap pelaksanaan

${ }^{1}$ Abdurrahman, Masalah-masalah Pencabutan Hak-hak Atas Tanah dan Pengadaan Tanah Bagi Pelaksanaan Pembangunan Untuk Kepentingan Umum di Indonesia, Citra Aditya Bakti, Bandung, 1996, h.1. 
pembangunan.

Oleh karena itu, diperlukan adanya suatu kebijakan dalam perolehan tanah untuk pembangunan. Hal ini ditempuh dengan lembaga pengadaan tanah yang pengaturannya terdapat dalam peraturan perundang-undangan yaitu Peraturan Presiden No. 36 Tahun 2005 Tentang Pengadaan Tanah Bagi Pelaksanaan Pembangunan Untuk Kepentingan Umum diubah oleh Peraturan Presiden No. 65 Tahun 2006 Tentang Perubahan Atas Peraturan Presiden No. 36 Tahun 2005 Tentang Pengadaan Tanah Bagi Pelaksanaan Pembangunan Untuk Kepentingan Umum. Adanya pengaturan mengenai pengadaan tanah menjadi landasan hukum bagi pemerintah untuk mendapatkan tanah bagi pelaksanaan pembangunan untuk kepentingan umum serta menjadi jaminan bagi pemegang hak atas tanah untuk mendapatkan ganti rugi yang layak, sehingga memberikan kelangsungan hidup yang lebih baik dari tingkat kehidupan sosial ekonomi sebelum terkena pengadaan tanah.

Ganti rugi yang layak bagi pemegang hak atas tanah bertujuan untuk menghormati hak-hak pemegang tanah yang telah bersedia untuk melepaskan atau menyerahkan hak atas tanahnya kepada negara. Pengaturanpengaturan yang terkaitmengenai pengadaan tanah beberapa kali telah mengalami perubahan. Perubahan-perubahan tersebut dimaksudkan untuk lebih menghormati dan menjamin hak-hak dari pemegang hak atas tanah. Dalam praktik pengadaan tanah untuk kepentingan umum, apabila tidak terjadi kesepakatan ganti rugi dapat dilaksanakan dengan konsinyasi. ${ }^{2}$ Dengan kata lain, adanya konsinyasi ini tidak memberikan pilihan kepada pemegang hak atas tanah selain melepaskan atau menyerahkan hak atas tanah. Secara normatif, konsinyasi diperbolehkan, lalu bagaimana perlindungan hukum bagi pemegang hak atas tanah serta akibathukumbagiinstansipemerintah selaku pihak yang memerlukan tanah. Ada kalanya dalam realitas, praktik pengadaan tanah masih banyak dijumpai terabaikannya hakhak pemegang hak atas tanah terlebih bagi kaum minoritas dan rakyat kecil. Mereka mengalami pereduksian kesejahteraan akibat adanya pelepasan atau penyerahan hak atas tanahnya untuk kepentingan pihak yang memerlukan tanah, dalam hal ini yaitu Pemerintah. Secara otomatis hal tersebut tentu telah melanggar prinsip-prinsip Hak Asasi Manusia yang secara tegas diakui oleh konstitusi sehubungan dengan prinsip kelangsungan hidup yang layak.

Terkait dengan hal tersebut perlu dikaji mengenai bentuk perlindungan hukum dalam penetapan ganti rugi terkait dengan pengadaan tanah untuk kepentingan umum sertaakibathukum denganadanyakonsinyasi bagi pemegang hak atas tanah dan instansi pemerintah, sehingga dapat memberikan perlindungan serta penghormatan terhadap hak-hak pemegang hak atas tanah, karena tanah sebagai salah satu unsur penting dalam pembangunan nasional penggunaanya harus dapat mewujudkan kesejahteraan, kebahagiaan dan keadilan bagi seluruh rakyat Indonesia.

2 Konsinyasi $=$ penitipan ganti rugi di pengadilan 
Pengaturan dan Prosedur Pengadaan Tanah untuk Kepentingan Umum

Pemerintah dalam melaksanakan pembangunan memerlukan tanah sebagai media pembangunan. Untuk itu dibentuk suatu lembaga pengadaan tanah. Adapun konsep pengadaan tanah menurut Pasal 1 angka 3 Peraturan Presiden No. 65 Tahun 2006, yaitu pengadaan tanah adalah setiap kegiatan untuk mendapatkan tanah dengan cara memberikan ganti rugi kepada yang melepaskan atau menyerahkan tanah, bangunan, tanaman, dan benda-benda yang berkaitan dengan tanah. Dari konsep tersebut, maka pengadaan tanah dilakukan dengan penyerahan atau pelepasan hak atas tanah dari pemegang tanah kepada instansi Pemerintah yang memerlukan tanah.

Pengaturan mengenai pengadaan tanah mengalami beberapa kali perubahan dan penyempurnaan. Sebelumnya, pada ketentuan Peraturan Menteri Dalam Negeri No. 15 Tahun 1975 lembaga yang digunakan dalamhalperolehantanahadalahpembebasan tanah. Ternyata, pada masa berlakunya banyak permasalahan yang timbul. Atas dasar permasalahan-permasalahan tersebut maka Presiden pada tanggal 17 Juni 1993 menerbitkan Keputusan Presiden (Keppres) No. 55 Tahun 1993 Tentang Pengadaan Tanah Bagi Pelaksanaan Pembangunan Untuk Kepentingan Umum dengan maksud untuk membuat pengaturan baru dalam kaitannya dengan perolehan hak atas tanah untuk kepentingan Pemerintah maupun perusahaan swasta, yang memberikan perlindungan hukum bagi pemegang hak atas tanah dan upaya untuk menyelesaikan permasalahan-permasalahan. Dengan berlakunya Keputusan Presiden No. 55 tahun 1993 maka perolehan tanah menggunakan lembaga hukum pengadaan tanah. Pada tanggal 3 Mei 2005, diterbitkan Peraturan Presiden No. 36 Tahun 2005 Tentang Pengadaan Tanah Bagi Pelaksanaan Pembanguan Untuk Kepentingan Umum yang mencabut Keputusan Presiden No. 55 Tahun 1993.

Terbitnya Peraturan Presiden No. 36 Tahun 2005 dilatarbelakangi adanya ketentuan dalam Undang-undang No. 10 Tahun 2004 bahwa Keputusan Presiden tidak lagi termasuk jenis peraturan perundangundangan. Jika dianalisis, Peraturan Presiden No. 36 Tahun 2005 ini bertentangan dengan Undang-undang No. 10 tahun 2004. Perpres ini tidak didasarkan pada Undangundang atau Peraturan Pemerintah tentang pengadaan tanah. Seharusnya, ketentuan ini tersebut berbentuk Undang-undang karena dalam substansinya menyangkut soal hak asasi manusia (HAM). Ini akan mendapatkan reaksi yang sangat macam-macam dari masyarakat menyangkut persoalan HAM, dalam hal ini menyangkut soal hak milik perseorangan atas tanah. ${ }^{3}$ Pada tanggal 5 Juni 2006, Peraturan Presiden No. 36 Tahun 2005 diubah oleh Peraturan Presiden No. 65 tahun 2006 tentang Perubahan Atas Peraturan Presiden No. 36 tahun 2005 tentang Pengadaan Tanah Bagi Pelaksanaan Pembangunan Untuk Kepentingan Umum. Peraturan Presiden No. 36 Tahun 2005

3 Maria S.W. Sumardjono, "Perpres No. 36 Tahun 2005 Bukan Untuk Sengsarakan Rakyat”. Harian Kompas. Jakarta, 12 Juni 2005, h.4. 
dilaksanakan oleh Peraturan Kepala Badan Pertanahan Nasional No. 3 tahun 2007.

Pihak yang memerlukan tanah dalam pengadaan tanah untuk kepentingan umum adalah instansi Pemerintah. Pengadaan tanah untuk kepentingan umum dilaksanakan dengan bantuan Panitia Pengadaan Tanah. Perolehan tanah dalam pengadaan tanah bagi pelaksanaan pembangunan untuk kepentingan umum oleh instansi pemerintah yang memerlukan tanah dilaksanakan melalui pelepasan atau penyerahan hak atas tanah. Dengan pelepasan atau penyerahan hak atas tanah ini tidak berakibat hak atas tanah berpindah dari pemegang haknya kepada instansi Pemerintah yang memerlukan tanah, melainkan hak atas tanah menjadi hapus dan tanahnya kembali menjadi tanah yang dikuasai langsung oleh Negara. ${ }^{4}$

Pengadaan tanah ditujukan untuk kepentingan umum, agar tidak terjadi penafsiran, maka perlu dibuat rumusan kriteria yang jelas mengenai kepentingan umum. ${ }^{5}$ Berdasarkan ketentuan pasal 18 UUPA, yang termasuk kepentingan umum adalah kepentingan bangsa dan Negara, serta kepentingan bersama rakyat. Maria S.W. Sumardjono menyatakan bahwa pada umumnya terdapat dua cara untuk mengungkapkan tentang doktrin kepentingan umum, yakni berupa $:^{6}$

\footnotetext{
${ }^{4}$ Urip Santoso, Hukum Pengadaan dan Pendaftaran Hak Atas Tanah. Fakultas Hukum Universitas Airlangga. Surabaya. 2009. h. 26.

5 Ibid., h. 28

${ }_{6}$ Maria S.W. Sumardjono (Selanjutnya disebut Maria S.W Sumardjono-1), Tanah Dalam Perspektif Hak Ekonomi Sosial dan Budaya, Kompas, Jakarta, Januari 2008. h. 241.
}

1. Pedoman umum, yang secara umum menyebutkan bahwa pengadaan tanah berdasarkan alasan kepentingan umum. Istilah-istilah yang sering digunakan secara bergantian untuk mengungkapkan tentang pengertian "umum" tersebut, misalnya public atau social, general, common, atau collective, sedangkan untuk istilah "kepentingan" atau "purpose" sering diganti dengan need necessity, interest, function, utility atau use. Sesuai dengan sifatnya sebagai pedoman, maka hal ini memberikan kebebasan bagi eksekutif untuk menyatakan suatu proyek memenuhi syarat untuk kepentingan umum dengan menafsirkan pedoman tersebut.

2. Penyebutan kepentingan umum dalam suatu daftar kegiatan yang secara jelas mengidentifikasi tujuannya : sekolah, jalan, bangunan-bangunan Pemerintah dan sebagainya, yang oleh peraturan perundang-undangan dipandanag bermanfaat untuk umum. Segala kegiatan di luar yang tercantum dalam daftar tersebut tidak dapat dijadikan alasan untuk pengadaan tanah.

Adapun kriteria kepentingan umum dalam pengadaan tanah ditetapkan dalam Pasal 5 Peraturan Presiden No. 65 Tahun 2006, yaitu pembangunan untuk kepentingan umum dilaksanakan oleh Pemerintah atau Pemerintah Daerah; dimiliki atau akan dimiliki oleh Pemerintah atau Pemerintah Daerah serta dalam bidang-bidang pembangunan yang meliputi : 
a. jalan umum, jalan tol, rel kereta api (di atas tanah, di ruang atas tanah, atau pun di ruang bawah tanah), saluran air minum/air bersih, saluran pembuangan air dan sanitasi;

b. waduk, bendungan, bendungan irigasi dan bangunan pengairan lainnya;

c. pelabuhan, bandar udara, stasiun kereta api, dan terminal;

d. fasilitas keselamatan umum, seperti tanggul penanggulangan bahaya banjir, lahar dan lain-lain bencana;

e. tempat pembuangan sampah

f. cagar alam dan cagar budaya

g. pembangkit, transmisi, dan distribusi tenaga listrik.

Peraturan Presiden ini memperluas pembatasan kepentingan umum dengan memuat kata "atau akan" dimiliki oleh Pemerintah/Pemerintah Daerah, serta mengahpus kata "tidak digunakan untuk mencari keuntungan". 7

Tahapan-tahapan dalam prosedur pengadaan tanah untuk kepentingan umum, yaitu : perencanaan pembangunan, penetapan Lokasi Pembangunan Untuk Kepentingan Umum dan Pelaksanaan Tugas Panitia Pengadaan Tanah dan Lembaga/Tim Penilai Harga Tanah. Sedangkan kegiatan yang dilakukan oleh Panitia Pengadaan Tanah Kabupaten/Kota dalam pengadaan tanah untuk kepentingan umum, yaitu : penyuluhan, identifikasi dan inventarisasi, Penunjukan Lembaga/Tim Penilai Harga Tanah,PelaksanaanMusyawarah, Keputusan Panitia Pengadaan Tanah Kabupaten/Kota,

\footnotetext{
7 Ibid., h. 42
}

Pembayaran Ganti Rugi, Pelepasan Hak Atas Tanah, dan Pengurusan Hak Atas Tanah.

\section{Penetapan Bentuk dan Besarnya Ganti Rugi}

Penghormatan dan penghargaan terhadap hak atas tanah yang diambil dalam pengadaan tanah bagi pelaksanaan pembangunan untuk kepentingan umum diwujudkan dalam pemberian ganti rugi. Bentuk dan besarnya ganti rugi merupakan unsur yang penting, karena terkait dengan kelangsungan hidup pemegang hak atas tanah. Realitasnya, hal terumit dalam pengadaan tanah adalah penentuan besarnya ganti rugi, apalagi bentuk ganti rugi berupa uang. Masalah yang berkenaan dengan ganti rugi dalam bentuk uang oleh Maria S.W. Sumardjono dapat dirinci sebagai berikut :

a. Ganti rugi dinilai terlalu rendah oleh pemegang hak atas tanah;

b. Gantirugiyang dituntutolehpemegang hak atas tanah terlalu tinggi yang tidak terlampau sulit untuk dipenuhi oleh pihak swasta, namun dapat menyulitkan bagi Pemerintah dalam melangsungkan proyek-proyeknya;

c. Ganti rugi tidak diterimakan langsung kepada mereka yang berhak dan/atau jumlahnya dipotong untuk keperluan yang tidak jelas. ${ }^{8}$

Konsep ganti rugi dalam pengadaan tanah untuk kepentingan umum yang dirumuskan dalam Pasal 1 angka 11

\footnotetext{
8 Maria S.W. Sumardjono. "Reformasi Hukum Pertanahan", Makalah, Seminar Sehari Memperingati Tri Dasawarsa UUPA, Fakultas Hukum Universitas Brawijaya, Malang, 13 Oktober 1991. h. 9.
} 
Peraturan Presiden No. 36 Tahun 2005, yaitu penggantian terhadap kerugian baik bersifat fisik dan/atau non fisik sebagai akibat pengadaan tanah diberikan kepada yang mempunyai tanah, bangunan, tanaman, dan/atau benda-benda lain yang berkaitan dengan tanah, yang dapat memberikan kelangsungan hidup yang lebih baik dari tingkat kehidupan sosial ekonomi sebelum terkena pengadaan tanah. Bila dikaitkan dengan dasar pembentukan Peraturan Presiden No. 36 Tahun 2005 dan Peraturan Presiden No. 65 Tahun 2006, sebagaimana dimuat dalam Konsideran "mengingat"nya, maka penggunaan istilah ganti rugi dalam pengadaan tanah ini adalah tidak tepat. Sebaiknya, istilah yang digunakan bukanlah ganti rugi melainkan penggantian yang layak. Kalau ganti rugi nilai penggantiannya bisa tidak layak, sedangkan penggantian yang layak nilai penggantiannya sudah pasti layak. ${ }^{9}$

Peraturan Presiden No. 36 Tahun 2005 yang diubah oleh Peraturan Presiden No. 65 Tahun 2006 mengatur Tentang apa saja yang diberi ganti rugi, bentuk ganti rugi, dan cara menetapkan ganti rugi atas tanah, bangunan, dan tanaman. Sifat ganti rugi menurut Peraturan Presiden No. 36 Tahun 2005, ada dua macam, yaitu ganti rugi bersifat fisik, diberikan untuk tanah, bangunan, tanaman, dan/atau benda-benda lain yang berkaitan dengan tanah dan ganti rugi bersifat non fisik, nilai penggantian dapat memberikan kelangsungan hidup yang lebih baik dari tingkat kehidupan sosial ekonomi sebelu

9 Urip Santoso, Hukum Pengadaan dan Pendaftaran Hak Atas Tanah. Fakultas Hukum Universitas Airlangga. Surabaya. 2009. h. 46. terkena pengadaan tanah. Namun Peraturan Presiden No. 36 Tahun 2005 tidak mengatur lebih lanjut dan rinci apa yang dimaksudkan dengan ganti rugi yang bersifat non fisik dan bagaimana menetapkan atau menghitung ganti rugi yang bersifat non fisik tersebut. Maria S.W. Sumardjono menyatakan bahwa kerugian yang bersifat non fisik meliputi hilangnya pekerjaan, bidang usaha, sumber penghasilan, dan sumber pendapatan lain yang berdampak terhadap penurunan tingkat kesejahteraan seseorang. Alternatif ganti kerugiannya antara lain meliputi penyediaan lapangan kerja pengganti, bantuan pelatihan dan fasilitas kredit. ${ }^{10}$

Ganti rugi dalam pengadaan tanah bagi pelaksanaan pembangunan untuk kepentingan umum diberikan untuk hak atas tanah, bangunan, tanaman, dan benda-benda lain yang berkaitan dengan tanah. Bentuk ganti rugi menurut Pasal 13 Peraturan Presiden No. 36 Tahun 2005 diubah oleh Pasal 13 Peraturan Presiden No.65 Tahun 2006, yaitu berupa uang; dan/atau tanah pengganti; permukiman kembali; dan/ atau gabungan dari dua atau lebih bentuk ganti rugi sebagaimana dimaksud dalam huruf a,huruf b, dan huruf c serta bentuk lain yang disetujui oleh pihak-pihak yang bersangkutan. Untuk hak ulayat masyarakat hukum adat, bentuk ganti rugi yaitu pembangunan fasilitas umum atau bentuk lain yang bermanfaat bagi masyarakat setempat.

Penetapan ganti rugi seringkali menemui kendala, antara lain tidak tercapainya kesepakatan mengenai

\footnotetext{
10 Maria S.W. Sumardjono-11, Op.cit, h. 105.
} 
besarannya. Oleh karena itu, Pasal 15 ayat (1) Peraturan Presiden No. 65 Tahun 2006 mengatur dasar perhitungan besarnya ganti rugi sebagai berikut :

a. Nilai Jual Obyek Pajak atau nilai nyata/ sebenarnya dengan memperhatikan Nilai Jual Obyek Pajak tahun berjalan berdasarkan penilaian Lembaga/Tim Penilai Harga Tanah yang ditunjuk oleh Panitia;

b. Nilai jual bangunan yang ditaksir oleh perangkat daerah yang bertanggung jawab di bidang bangunan;

c. Nilai jual tanaman yang ditaksir oleh perangkat daerah yang bertanggung jawab di bidang pertanian.

Yang menilai harga tanah adalah Lembaga/Tim Penilai Harga Tanah, sedangkan yang menetapkan harga tanah adalah Panitia Pengadaan Tanah Kabupaten/ Kota. Hasil penilaian harga tanah yang dilakukan oleh Lembaga/Tim Penilai Harga Tanah diserahkan kepada Panitia Pengadaan Tanah Kabupaten/Kota, untuk dipergunakan sebagai dasar musyawarah antara instansi Pemerintah yang memerlukan tanah dengan para pemegang hak atas tanah. Berkenaan dengan penetapan ganti rugi, Abdurrahman menegaskan bahwa yang terpenting justru bukannya pada pedoman besarnya ganti rugi berdasarkan NJOP, akan tetapi berdasarkan musyawarah antara Panitia Pengadaan Tanah dengan pemegang hak atas tanah yang didalamnya memuat kesepakatan antara kedua belah pihak tersebut. ${ }^{11}$ Dalam menentukan besarnya ganti rugi, sebaiknya harus ada keseimbangan harga antara

11 Abdurrahman, Op.cit., h. 146 tuntutan pemegang hak atas tanah dengan kesanggupan instansi Pemerintah.

\section{Penitipan Ganti Rugi Berbentuk Uang Kepada Pengadilan Negeri}

Dalam Peraturan Presiden No.3 Tahun 2005 dan telah dirubah oleh Peraturan Presiden No. 65 Tahun 2006 diatur mengenai penitipan ganti rugi berbentuk uang kepada pengadilan negeri dalam Pasal 10, yaitu dalam hal kegiatan pembangunan untuk kepentingan umum yang tidak dapat dialihkan atau dipindahkan secara teknis tata ruang ke tempat atau lokasi lain, maka musyawarah dilakukan dalam jangka waktu paling lama 120 (seratus dua puluh) hari kalender terhitung sejak tanggal undangan pertama dan apabila setelah diadakannya musyawarah sebagaimana dimaksud pada ayat (1) tidak tercapai kesepakatan, Panitia Pengadaan Tanah menetapkan bentuk dan besarnya ganti rugi sebagaimana dimaksud dalam pasal 13 huruf a dan menitipkan ganti rugi uang kepada Pengadilan Negeri yang wilayah hukumnya meliputi lokasi tanah yang bersangkutan. Kemudian apabila terjadi sengketa kepemilikan setelah penetapan ganti rugi sebagaimana dimaksud pada ayat (1), maka Panitia Pengadaan Tanah menitipkan ganti rugi uang kepada Pengadilan Negeri yang wilayah hukumnya meliputi lokasi tanah yang bersangkutan.

Herman Slaats dkk menyatakan bahwa salah satu yang controversial di dalam Perpres No. 36 Tahun 2005 adalah tentang consignatie atau lembaga penitipan uang ganti kerugian kepada pengadilan apabila tidak tercapai kesepakatan mengenai 
ganti kerugian antara Pemerintah dengan pemegang hak atas tanah. ${ }^{12}$ Maria S.W. Sumardjono menyatakan bahwa penitipan ganti kerugian kepada Pengadilan Negeri berdasarkan dua alasan, yaitu pertama kegiatan pembangunan untuk kepentingan umum tidak dapat dipindahkan secara teknis tata ruang ke lokasi lain dan kedua musyawarah telah berjalan 90 hari kalender namun tidak tercapai kata sepakat. Keppres tidak memuat ketentuan serupa itu. Perpres telah keliru menerapkan konsep penitipan ganti kerugian pada pengadilan yang dianalogkan dengan konsep penitipan uang yang terkait utang piutang dalam Pasal 1404 KUH Perdata. Jika belum ada kata sepakat tetapi ganti kerugian ditetapkan dan dititipkan di Pengadilan, dapat dikatakan, selain keliru, hal itu merupakan pemaksaan kehendak oleh satu pihak dan mengabaikan prinsip kesetaraan antara pemegang hak atas tanah dengan pihak yang memerlukan tanah. ${ }^{13}$ Dengan adanya praktik konsinyasi, hal tersebut menimbulkan permasalahan dalam hal pengadaan tanah untuk kepentingan umum.

Boedi Harsono menyatakan bahwa dengan dilakukan konsinyasi (penitipan uang ganti rugi) itu, maka pihak yang memerlukan tanah menganggap dirinya telah memenuhi kewajibannya membayar ganti kerugian. Terserah kepada pemilik tanah untuk mengambilnya. Untuk selanjutnya

12 Herman Slaats dkk, Masalah Tanah di Indonesia Dari Masa ke Masa, Lembaga Studi Hukum dan Ekonomi Fakultas Hukum Universitas Indonesia. Jakarta, 2007. h. 101

1313 Maria S.W. Sumardjono, (Selanjutnya disebut Maria S.W Sumardjono-II), Kebijakan Pertanahan Antara Regulasi dan Implementasi, Kompas, Jakarta. 2005. h. 105 ia tidak lagi berurusan dengan pemilik tanah, hingga tanah yang bersangkutan boleh diambil dan digunakan. Pemilik tanah dipersilahkan berhubungan dengan Ketua Pengadilan Negeri. ${ }^{14}$ Menurut Ali Sofwan Husein, praktek konsinyasi dalam pengadaan tanah sebenarnya tidak dibenarkan oleh hukum karena lembaga konsinyasi itu mensyaratkan adanya hubungan hukum (perdata) terlebih dahulu antara para pihak sebelum uang tersebut dititipkan (dikonsinyasikan) di pengadilan. Sedangkan dalam pengadaan tanah tidak ada hubungan yang dimaksudkan itu. Dari sini tampak jelas, bahwa sang penguasa mengambil gampangnya saja untuk mencari keabsahan dan legalitas atas tindakannya, yaitu ketika tidak tercapai kesepakatan ganti rugi, maka uang yang dianggarkan itu langsung dititipkan di pengadilan dan kemudian menganggap masalah penggusuran tanah beres dan selesai. ${ }^{15}$

\section{Perlindungan Hukum dalam Hal Penetapan Ganti Rugi}

Perlindungan hukum bagi pemegang hak atas tanah mengandung pengertian bahwa pemegang hak atas tanah berhak dilindungi hak -haknya terkait dengan pengadaan tanah yang dilakukan oleh instansi Pemerintah yang memerlukan tanah. Adapun konsep yang dijabarkan oleh Philipus M. Hadjon dalam bukunya disebutkan bahwa pengertian perlindungan

\footnotetext{
14 Boedi Harsono, “Aspek Yuridis Penyediaan Tanah", Majalah Hukum dan Pembangunan, Nomor 2 Tahun XX. Fakultas Hukum Universitas Indonesia, Jakarta, April 1990. h. 168.

15 Ali Sofwan Husein, Konflik Pertanahan, Pustaka Sinar Harapan, Jakarta, 1997. h. 94.
} 
hukum bagi rakyat berkaitan dengan rumusan yang dalam kepustakaan berbahasa Belanda berbunyi "rechtsbescherming van de burgers tegen de overhead" dan dalam kepustakaan berbahasa Inggris "legal protection of the individual in relation to acts of administrative authorities". ${ }^{16}$ Di sebutkan pula bahwa ada dua macam perlindungan hukum bagi rakyat, yaitu perlindungan hukum preventif dan perlindungan hukum represif. Pada perlindungan hukum yang preventif, kepada rakyat diberikan kesempatan untuk mengajukan keberatan (inspraak) atau pendapatnya sebelum suatu keputusan pemerintah mendapat bentukyang definitif. ${ }^{17}$ Sehingga tujuan dari perlindungan hukum preventif adalah mencegah terjadinya sengketa sedangkan perlindungan hukum yang represif bertujuan untuk menyelesaikan sengketa. ${ }^{18}$ Perlindungan hukum yang preventif sangat besar artinya bagi tindak pemerintahan yang didasarkan kepada kebebasan bertindak karena dengan adanya perlindungan hukum yang preventif pemerintah terdorong untuk bersikap hatihati dalam mengambil keputusan yang didasarkan pada diskresi. ${ }^{19}$ Perlindungan hukum sebagai suatu gambaran dari fungsi hukum dimana hukum dapat memberikan suatu keadilan, ketertiban, kepastian, kemanfaatan, kedamaian, ketentraman bagi segala kepentingan manusia yang ada di dalam masyarakat.

Dalam praktik pengadaan tanah bagi pelaksanaan pembangunan untuk

${ }_{16}$ Prof. Dr. Philipus M. Hadjon, Perlindungan

Hukum Bagi Rakyat Indonesia, Peradaban. 2007. h. 1.

17 Prof. Dr. Philipus M. Hadjon. Op.cit.,,h. 2

18 Ibid., h. 2.

19 Ibid., h.2. kepentingan umum, ganti rugi terhadap bangunan, tanaman, dan benda-benda lain yang berkaitan dengan tanah tidak banyak menemui hambatan dalam menetapkan besarnya. Namun demikian, permasalahan yang sering timbul adalah mengenai penetapan besarnya ganti rugi terhadap hak atas tanah. ${ }^{20}$ Antara para pemegang hak atas tanah dengan instansi pemerintah yang memerlukan tanah sering sulit mencapai kesepakatan dalam musyawarah mengenai besarnya ganti rugi. Oleh karenanya, unsur terpenting terletak pada bagaimana musyawarah tersebut agar terjadi kesepakatan sehingga tidak ada pihak yang dirugikan. Musyawarah dilakukan dengan kekeluargaan dan tidak ada yang mementingkan pihak manapun. Musyawarah yang dilakukan oleh para pihak yang terkait menurut Hasanudin adalah betul-betul musyawarah dan bukan pengarahan (apalagi pemaksaan), sehingga proses kegiatan saling mendengar dengan sikap saling menerima pendapat dan keinginan yang didasarkan atas kesukarelaan antara pihak-pihak yang bermusyawarah dapat dilaksanakan dengan baik. $^{21}$

Pemegang hak atas tanah diberikan perlindungan hukum terhadap ketidaksepakatan dalam hal penetapan ganti rugi, hal ini diatur dalam Pasal 17 dan 18 Peraturan Presiden No. 36 tahun 2005. Pemegang hak atas tanah dapat mengajukan keberatan kepada Bupati/Walikota atau Gubernur atau Menteri Dalam Negeri disertai

\footnotetext{
20 Urip Santoso,Op.cit h. 52.

21 A.A. Oka Mahendra dan Hasanudin, Tanah dan Pembangunan Tinjauan Dari Segi Yuridis dan Politis, Pustaka Manikgeni. Denpasar. 1997. h. 41.
} 
dengan penjelasan dan alasan keberatan. Bupati/Walikota atau Gubernur atau Menteri Dalam Negeri setelah mendengar dan mempelajari pendapat dan keinginan pemegang hak atas tanah serta pertimbangan panitia pengadaan tanah dapat mengukuhkan atau mengubah keputusan panitia pengadaan tanah mengenai bentuk dan/atau besarnya ganti rugi yang akan diberikan. Apabila pemegang hak atas tanah tidak menerima upaya penyelesaian tersebut diatas, maka dapat diajukan usul penyelesaian dengan cara pencabutan hak atas tanah berdasarkan Undang-undang Nomor 20 Tahun 1961 tentang Pencabutan Hak-hak Atas Tanah Dan Benda-benda Yang Ada Di atasnya. Dari uraian diatas, pemegang hak atas tanah hanya dapat mengajukan keberatan terhadap besarnya ganti rugi, bukan terhadap hak atas tanah yang akan dipergunakan untuk kepentingan umum. Konsekuensinya, pemegang hak atas tanah tidak ada pilihan lain selain melepaskan atau menyerahkan hak atas tanah.

\section{Akibat Penitipan Ganti Rugi Kepada Pengadilan Negeri}

Sebelumnya telah dibahas mengenai dasar yang mengatur tentang konsinyasi (penitipan ganti rugi) kepada Pengadilan Negeri, sebagai upaya yang dibenarkan secara normatif apabila tidak terjadi kesepakatan mengenai besarnya ganti rugi antara pemegang hak atas tanah dengan instansi pemerintah. Jika diteliti, ketentuan Pasal 17 dan Pasal 18 Peraturan Presiden No. 36 Tahun 2005 dengan ketentuan Pasal 17 dan Pasal 18 Peraturan Presiden No. 36
Tahun 2005 tidak sinkron. Ketidaksinkronan ini karena dalam Pasal 10 menetapakan bahwa Ketua Panitia Pengadaan Tanah Kabupaten/Kota menerbitkan keputusan mengenai besarnya ganti rugi setelah musyawarah antara instansi pemerintah yang memerlukan tanah dengan pemegang hak atas tanah selama 120 (seratus dua puluh) hari tidak mencapai kesepakatan dan menitipkan ganti rugi uang kepada Pengadilan Negeri yang wilayah hukumnya meliputi lokasi tanah yang bersangkutan, sedangkan Pasal 17 menetapkan bahwa pemegang hak atas tanah yang tidak menerima keputusan Panitia Pengadaan Tanah dapat mengajukan keberatan kepada Bupati/Walikota atau Gubernur atau Menteri Dalam Negeri sesuai kewenangan disertai dengan penjelasan mengenai sebab-sebab dan alasan keberatan tersebut. ${ }^{22}$

Hal ini menimbulkan ketidakpastian hukum bagi pemegang hak atas tanah dan sebagai akibatnya instansi pemerintah dapat menjadikan ketidaksinkronan ini sebagai celah untuk memperoleh tanah dengan mudan dan tentunya dengan ganti rugi yang rendah. Dalam praktik, upaya konsinyasi sering ditempuh oleh instansi pemerintah yang memerlukan tanah agar proses pengadaan tanah bisa dilakukan. Dengan telah menitipkan ganti rugi, instansi pemerintah yang memerlukan tanah beranggapan telah melaksanakan kewajiban memberikan ganti rugi yang layak kepada pemegang hak atas tanah dan merasa sudah berhak mengambil tanah-tanah hak. Terserah kepada pemegang hak atas tanah mau atau

\footnotetext{
${ }^{22}$ Urip Santoso, Op.cit. h. 68.
} 
tidak mengambil ganti rugi uang kepada Pengadilan Negeri di wilayah hukumnya meliputi lokasi tanah yang bersangkutan, itu bukan urusan instansi Pemerintah yang memerlukan tanah. Tindakan tersebut merupakan pemaksaan kehendak, perlakuan sepihak, perampasan hak, tindakan sewenang-wenang oleh instansi Pemerintah yang memerlukan tanah, dan tidak adanya penghormatan terhadap hak-hak yang sah atas tanah. Pengambilan tanah-tanah hak oleh instansi Pemerintah yang memerlukan tanah merupakan pencabutan hak atas tanah secara terselubung, dan hal ini dapat dikatakan telah melangkahi kewenangan presiden, karena pengambilan tanah-tanah hak secara sepihak untuk kepentingan umum adalah kewenangan Presiden melalui upaya pencabutan hak atas tanah. ${ }^{23}$

Tidak dapat dibenarkan instansi Pemerintah yang memerlukan tanah mengambil tanah pemegang hak atas tanah sebelum terjadi kesepakatan dalam musyawarah mengenai bentuk ganti rugi dengan dalail konsinyasi. Karena konsinyasi dibenarkan apabila pemegang hak atas tanah telah menandatangani surat pernyataan pelepasan atau penyerahan, tetapi tidak mau menerima ganti rugi. Namun jika belum terjadi kesepakatan, maka konsinyasi tidak bisa dianggap sebagai dasar untuk pengambilan hak atas tanah, karena hal tersebut tidak memberikan perlindungan hukum bagi pemegan hak atas tanah. Terlebih juga, dalam Peraturan Presiden No. 36 Tahun 2005, Peraturan Presiden No. 65 Tahun 2006, dan Peraturan Kepala

23 Ibid., h. 64.
Badan Pertanahan nasional tidak ada satu pasal dan ayat pun yang memperbolehkan hak atas tanah dapat diambil oleh instansi Pemerintah yang memerlukan tanah setelah Panitia Pengadaan Tanah Kabupaten/ Kota menitipkan ganti rugi uang kepada Pengadilan Negeri yang wilayah hukumnya meliputi lokasi tanah yang bersangkutan. ${ }^{24}$

\section{PENUTUP}

Musyawarah yang dilakukan sebelum dilakukan pelepasan atau penyerahan dari pemegang hak atas tanah kepada instansi Pemerintah yang memerlukan tanah bertujuan agar terjadi kesepakatan antara pemegang hak atas tanah dengan instansi Pemerintah yang memerlukan tanah mengenai bentuk dan besarnya ganti rugi yang akan diterima oleh pemegang hak atas tanah yang terkena pengadaan tanah untuk kepentingan umum. Musyawarah yang dilakukan harus memperhatikan hakhak pemegang hak atas tanah serta adanya kesetaraan dalam menyampaikan keinginan dan pendapat.

Dalam menentukan besarnya ganti rugi kedua belah pihak menggunakan pedoman harga dari Lembaga/Tim Penilai harga tanah, namun harga tersebut tidak bersifat mutlak tetapi dipandang sebagai acuan saja. Yang diutamakan dalam penentuan besarnya ganti rugi adalah hasil kesepakatan dalam muyawarah, sehingga tidak ada satu pihak yang dirugikan dan diuntungkan dalam pengadaan tanah untuk kepentingan umum. Parameter untuk mengukur layak atau tidak layak dapat berpedoman kepada

\footnotetext{
24 Ibid., h. 63.
} 
pengaturan Peraturan Presiden No. 36 Tahun 2005 bahwa disebutkan dalam konsep ganti rugi salah satu unsurnya yaitu dapat memberikan kelangsungan hidup yang lebih baik dari tingkat kehidupan sosial ekonomi sebelum terkena pengadaan tanah. Dari konsep tersebut, dapat disimpulkan bahwa pemberian ganti rugi kepada pemegang hak atas tanah tidak boleh mengakibatkan pereduksian kesejahteraan sosial dan ekonomi pemegang hak tas tanah. Apabila pemegang hak tas tanah merasa ganti rugi yang diberikan oleh instansi Pemerintah yang memerlukan tanah tidak layak dan dapat mengakibatkan kerugian yang besar secara sosial ekonomi, maka pemegang hak atas tanah tersebut dapat mengajukan keberatan kepada Bupati/Walikota atau Menteri dalam Negeri. Pengajuan keberatan tersebut disertai dengan penjelasan dan alasan keberatan. Setelah di dengar dan dipelajari apabila ternyata ganti rugi yang diberikan tidak layak maka dapat diubah keputusan dari Panitia Pengadaan Tanah mengenai bentuk/atau besarnya ganti rugi yang akan diberikan.

Dengan dititipkannya ganti rugi ke Pengadilan Negeri oleh instansi Pemerintah yang memerlukan tanah tidak memberikan perlindungan hukum bagi pemegang aha atas tanah selama belum terjadi kesepakatan yang diwujudkan dalam penandatanganan surat pernyataan pelepasan atau penyerahan hak atas tanah. Hal ini dapat dikategorikan sebagai tindakan sewenang-wenang, karena tidak ada ketentuan mengenai diperbolehkannya instansi Pemerintah yang memerlukan tanah mengambil hak atas tanah pemegang hak tas tanah setelah dititipkannya ganti rugi ke Pengadilan Negeri.

Terdapat ketidaksinkronan dalam Pengaturan-pengaturan dalam Peraturan Presiden No. 36 Tahun 2005 sebagaimana telah diubah dengan Peraturan Presiden No. 65 Tahun 2006, sehingga perlu kiranya untuk dilakukan peninjauan kembali terhadap Peraturan Presiden tersebut. Ketidaksinkronan pengaturan tersebut menimbulakan perbedaan penafsiran dan hal tersebut memicu permasalahanpermasalahan dalam pengadaan tanah untuk kepentingan umum. Dirasa perlu untuk meningkatkan Peraturan Presiden mengenai pengadaan tanah untuk kepentingan umum menjadi Undang-undang. Hal ini dikarenakan dalam Peraturan Presiden No. 36 Tahun 2005 sebagaimana telah diubah dengan Peraturan Presiden No. 65 Tahun 2006 mengatur tentang hak asasi manusia berupa hak dan kewajiban pemegang hak atas tanah dalam pengadaan tanah bagi pelaksanaan pembangunan untuk kepentingan umum.

\section{DAFTAR BACAAN}

Abdurrahman, Masalah-masalah Pencabutan Hak-hak Atas Tanah dan Pengadaan Tanah Bagi Pelaksanaan Pembangunan Untuk Kepentingan Umum di Indonesia, Citra Aditya Bakti, Bandung, 1996. 
Harsono, Boedi, “Aspek Yuridis Penyediaan Tanah", Majalah Hukum dan Pembangunan, Nomor 2 Tahun XX. Fakultas Hukum Universitas Indonesia, Jakarta, April 1990.

Hasanudin, A.A. Oka Mahendra, Tanah dan Pembangunan Tinjauan Dari Segi Yuridis dan Politis, Pustaka Manikgeni. Denpasar. 1997.

Husein,AliSofwan,KonflikPertanahan, Pustaka Sinar Harapan, Jakarta, 1997.

M. Hadjon, Philipus, Perlindungan Hukum Bagi Rakyat Indonesia, Peradaban. 2007.

Santoso, Urip, Hukum Pengadaan dan Pendaftaran Hak Atas Tanah. Fakultas Hukum Universitas Airlangga. Surabaya. 2009.

Slaats, Herman dkk, Masalah Tanah di Indonesia Dari Masa ke Masa, Lembaga Studi Hukum dan Ekonomi Fakultas Hukum Universitas Indonesia. Jakarta, 2007.

Sumardjono, Maria S.W., Kebijakan Pertanahan Antara Regulasi dan Implementasi, Kompas, Jakarta. 2005.

Sumardjono, Maria S.W., "Perpres No. 36 Tahun 2005 Bukan Untuk Sengsarakan Rakyat". Harian Kompas. Jakarta, 12 Juni 2005.

Sumardjono, Maria S.W., "Reformasi Hukum Pertanahan", Makalah, Seminar Sehari Memperingati Tri Dasawarsa UUPA, Fakultas Hukum Universitas Brawijaya, Malang, 13 Oktober 1991.
Sumardjono, Maria S.W., Tanah Dalam Perspektif Hak Ekonomi Sosial dan Budaya, Kompas, Jakarta, Januari 2008.

\section{Peraturan Perundang-undangan}

Undang-undang Dasar 1945

\section{UUPA}

Peraturan Presiden No. 36 Tahun 2005 Tentang Pengadaan Tanah Bagi Pelaksanaan Pembangunan Untuk Kepentingan Umum.

Peraturan Presiden No. 65 Tahun 2006 Tentang Perubahan Atas Peraturan Presiden No. 36 Tahun 2005 Tentang Pengadaan Tanah Bagi Pelaksanaan Pembangunan Untuk Kepentingan Umum.

Peraturan Kepala Badan Pertanahan Nasional No. 3 tahun 2007 Tentang Ketentuan Pelaksanaan Peraturan Presiden No. 36 Tahun 2005 Tentang Pengadaan Tanah Bagi Pelaksanaan Pembangunan Untuk Kepentingan Umum sebagaimana telah diubah dengan Peraturan Presiden No. 65 Tahun 2006 Tentang Pengadaan Tanah Bagi Pelaksanaan Pembangunan Untuk Kepentingan Umum.

Undang-undang No. 20 Tahun 1961 Tentang Pencabutan Hak Atas Tanah 